\title{
tam \\ Dioxin Formation in Biomass Gasification: A Review
}

\author{
Aysan Safavi *(D), Christiaan Richter (D) and Runar Unnthorsson (D)
}

School of Engineering and Natural Sciences, University of Iceland, VR-II, Hjardarhaga 6, 107 Reykjavik, Iceland; cpr@hi.is (C.R.); runson@hi.is (R.U.)

* Correspondence: sms36@hi.is

\begin{abstract}
The amount of PCDD/F emissions produced by gasification operations is often within standard limits set by national and international laws $\left(<0.1 \mathrm{ng} \mathrm{TEQ} / \mathrm{Nm}^{3}\right)$. However, a recent assessment of the literature indicates that gasification cannot always reduce PCDD/Fs emissions to acceptable levels, and thus a common belief on the replacement of incineration with gasification in order to reduce PCDD/Fs emissions seems overly simplistic. A review that summarizes the evidence on when gasification would likely result in environmentally benign emissions with PCDD/F below legal limits, and when not, would be of scientific and practical interest. Moreover, there are no reviews on dioxin formation in gasification. This review discusses the available data on the levels of dioxins formed by gasifying different waste streams, such as municipal solid wastes, plastics, wood waste, animal manure, and sewage sludge, from the existing experimental work. The PCDD/Fs formation in gasification and the operational parameters that can be controlled during the process to minimize PCDD/Fs formation are reviewed.
\end{abstract}

Keywords: biomass gasification; dibenzo-p-dioxins; dibenzofluorans; syngas

check for updates

Citation: Safavi, A.; Richter, C.; Unnthorsson, R. Dioxin Formation in Biomass Gasification: A Review. Energies 2022, 15, 700. https:// doi.org/10.3390/en15030700

Academic Editors: Andrea Di linebreak Carlo, Enrico Bocci and Vera Marcantonio

Received: 9 December 2021 Accepted: 10 January 2022

Published: 19 January 2022

Publisher's Note: MDPI stays neutral with regard to jurisdictional claims in published maps and institutional affiliations.

Copyright: (c) 2022 by the authors. Licensee MDPI, Basel, Switzerland. This article is an open access article distributed under the terms and conditions of the Creative Commons Attribution (CC BY) license (https:// creativecommons.org/licenses/by/ $4.0 /)$.

\section{Introduction}

Incineration of municipal solid waste (MSW) increased during the 1960s. The process recovers energy from waste and decrease the areas required for landfilling. Nevertheless, it contributes to the release of very toxic organic [1]. Incineration causes fly and bottom ashes, which release leachable toxic heavy metals, polychlorinated diben-zo-p-dioxins (PCDDs) and polychlorinated dibenzofluorans (PCDFs), and volatile organic compounds [2], especially for MSW incineration [3-5].

$\mathrm{PCDD} / \mathrm{Fs}$ are a group of toxic by-products coming from thermal processes that have serious carcinogenic and mutagenic effects [6,7]. After PCDD/Fs enter the atmosphere, dioxins are deposited onto soil/plant surfaces. Most plants uptake soil-deposited dioxins. Dioxins enter the animal food chain when animals consume these contaminated plants. Therefore, food sources serve as a primary intake of dioxin in humans [8-10]. Therefore, controlled measurement of PCDD/Fs emissions has received much attention as it is one of the most important aspects affecting public acceptance. The release of PCDD/F from incineration processes was first spotted in the late 1970s, and since then, researchers have been evaluating the emission of this compound produced from a series of thermal processes [11].

Due to their high toxicity, the dioxins emissions limit, determined by national and international organizations, is $0.1 \mathrm{ng}$ I-TEQm ${ }^{3}$, where I-TEQ (international toxic equivalent) is a single figure resulting from the product of the concentration and individual toxic equivalency factor values of each congener [12]. Incinerators emit PCDD/Fs and their concentration often exceeds the legal limit, which calls for an alternative waste treatment technology.

Waste gasification is a feasible alternative to incineration, tackles PCDD/Fs formation, and improves energy efficiency, which found application in the late 1990s [13]. In a gasifier, MSW, industrial waste, and biomass/wood [14], at 800 to $1400{ }^{\circ} \mathrm{C}$ in the presence of a 
gasifying agent (typically air, steam, nitrogen, carbon dioxide, oxygen, or a combination of these), can be converted into producer gas (a mixture of $\mathrm{H}_{2}, \mathrm{CO}$, etc.). Utilizing producer gas to generate electrical and thermal energy is the most dominant process in gasification; however, chemicals and liquid fuel may also be produced from the producer gas [15]. Residual carbon (mainly char), which results from incomplete conversion of the biomass, can be utilized for soil enhancement [12].

The measured amount of PCDD/Fs originating from gasification processes is usually within acceptable limits [16]. The producer gas can contain a lower amount of pollutants compared to the pollutants coming from the flue gas of an incinerator [17] thanks to fractional waste oxidation at high temperatures and a limited oxygen environment [18-20]. However, organic chlorinated compounds in the reactor and incomplete destruction of the PCDD/Fs present in the waste itself can result in some amounts of PCDD/Fs [15,21,22].

This current study offers a more comprehensive picture of PCDD/F formation in gasification. This review discusses the available data on the levels of dioxins formed by gasifying different waste streams, such as municipal solid wastes, plastics, wood waste, animal manure, and sewage sludge, from the existing experimental work. This article highpoints the prospect of using gasification technology in order to reduce the emission of $\mathrm{PCDD} /$ Fs to levels below regulatory or detection limits. We tried to cover all accessible articles that have been published since 1990 and perform a thorough assessment to frame this review, which is really missing in the field.

\section{Dioxin Formation in Gasification}

Assessing the environmental impacts of gasification technology is crucial to ensure the feasibility of the process. The real challenge/concern is the formation of harmful chemicals, especially PCDD/Fs. From the environmental perspective, it is the topmost priority to reduce PCDD/Fs formation and increase their capture. The following industries are among those producing high amounts of dioxins: plastic-coated wire incineration in which the burning of $\mathrm{Cu}$ electrical wiring that is treated with chlorine-containing PVC could be a driving force for dioxin formation. High-temperature and metal-containing processes, such as the sintering of Fe ore taking place in the steel industry, melting the $\mathrm{Cu}$ ore, splicing of electrical cables, and the process of reviving the catalyst in the petroleum refining industry, are other examples [23].

An organic material, a chlorine source, and a metallic catalyst (such as $\mathrm{Cu}, \mathrm{Fe}$, etc.) are the main ingredients for dioxin/furan formation. Dioxins form by the precursor route via reactions between aromatic rings containing chlorine (chlorophenols (CPs) and chlorobenzenes (CBs)) in the gas phase or by the de novo synthesis route in the postcombustion zone (reactions between unburnt carbon and chlorine sources with metallic catalysts) [24]. The temperature windows for the formation of PCDD/Fs are defined as 200-800 ${ }^{\circ} \mathrm{C}[5,25]$, where the reaction rate is maximized from 350 to $400{ }^{\circ} \mathrm{C}$ [26]. A detailed explanation of the PCDD/Fs formation mechanism can be found in our previous study [24]. In combustion processes, a low combustion temperature, humidity, poor turbulence and short residence time in the combustion zone, oxygen availability, and slow cooling process of flue gas in the critical temperature range could be the reasons for the formation of $\mathrm{PCDD} / \mathrm{F}$, as well as the presence of residual carbon, chloroaromatics, and polycyclic aromatic hydrocarbons (PAHs) $[1,12,27]$. Humidity has been shown to influence the product distribution more, driving it towards highly chlorinated congeners [27].

Halogens in the feed $[28,29]$ and catalytic metals $(\mathrm{Cu}, \mathrm{Fe}, \mathrm{Zn}$, etc.) [16] in fly ash boost formation of $\mathrm{PCDD} / \mathrm{Fs}$ are present in thermal processes [5,30]. Additionally, the reaction of dioxins with chlorine and unburned carbon in the presence of these metals can contribute to the de novo synthesis of PCDD/Fs and promote the formation of other organic chlorinated compounds [16,31-33]. The catalytic effect of the metal ions facilitates the reaction of $\mathrm{HCl}$ with $\mathrm{O}_{2}$ and release of $\mathrm{Cl}_{2}$ for chlorinating the aromatic rings that result in dioxin formation. Copper halides, such as $\mathrm{CuCl}$ and $\mathrm{CuCl}_{2}$, are known to be strong catalyst, acting as both a catalyst and chlorine source at once. These catalysts enhance the precursor route via the 
chlorination process, and the de novo synthesis route via chlorination of carbon as well as oxidative breakdown of carbonaceous material [34].

Zhang et al. [35] considered the influence of temperature and extrinsic and intrinsic oxygen on the formation of chloroaromatics, which are prerequisites for the synthesis of $\mathrm{PCDD} / \mathrm{Fs}$. This study provides useful information when designing the syngas combustion zone of gasification-combustion processes for MSW disposal. The results revealed that at low temperatures, intrinsic oxygen affects inhibition of chloroaromatics formation. At high temperatures, extrinsic oxygen had a strong inhibition effect on the formation of chloroaromatics [35]. Studies have shown that $\mathrm{Cl}$ radicals can be transformed to $\mathrm{HCl}$ over a designed homogeneous conversion, which inhibits PCDD/Fs formation in syngas. Nevertheless, $\mathrm{HCl}$ can simultaneously be oxidized and regenerate $\mathrm{Cl}$ radicals during the syngas combustion process. The presence of these radicals and hydrocarbon fragments could be a key path for the formation of chloroaromatics via chlorination reactions under an oxidative atmosphere. The results concluded that $\mathrm{O}_{2}$ has a considerable effect on the formation of chloroaromatics, and this depends on the competition between oxidation and chlorination [35].

Calcium-based chemical looping gasification is composed of an air reactor and gasifier. The system uses calcium oxide $(\mathrm{CaO})$ as a carrier between two reactors. The dioxin precursors available in biomass are attacked by $\mathrm{CaO}$ via absorption and decomposition. This hampers the $\mathrm{PCDD} / \mathrm{Fs}$ formation. In addition, $\mathrm{CaO}$ could also absorb $\mathrm{HCl}$ and prevent the formation of $\mathrm{Cl}_{2}$ from $\mathrm{HCl}$ [36-38]. The effectiveness of calcium-based chemical looping gasification on dioxin emissions and from heavy metal contamination wastes was studied by Cai et al. [39]. The results showed that the availability of steam and calcium-based sorbent can minimize PCDD/Fs formation. The presence of catalytic metals in the process is more effective in the synthesis of dioxin compared to chlorine and residual carbon. The catalytic activity of metals is in the following order: $\mathrm{Cu}>\mathrm{Fe}>\mathrm{Cr}>\mathrm{Zn}$. Calciumbased chemical looping gasification outcomes prove that the high $\mathrm{H}_{2}$ concentration in the process stimulates $\mathrm{HCl}$ formation instead of $\mathrm{CuCl}_{2}$; thus, this is favorable in hampering the formation of dioxins. At operating temperatures of 600 to $750{ }^{\circ} \mathrm{C}$, the valences of $\mathrm{Pb}, \mathrm{Cr}$, and $\mathrm{Cu}$ decreased; therefore, the process had a positive effect on the stabilization of heavy metals [39].

The operational conditions of the process, such as high temperature, oxygen deficiency along with maximizing the conversion of hydrocarbons that are being produced in pyrolysis, are possible approaches to reduce the formation of PCDD/Fs in gasification as compared to that of combustion [40]. The oxygen content in a gasification reactor is much lower than the theoretical oxygen content required for fuel combustion, resulting in much lower PCDD/Fs synthesis. Thus, the atmosphere of a gasification reactor is a reducing atmosphere [41].

Zwart et al. [42] analyzed the dioxin formation from refuse-derived fuel (RDF), wood, and sewage sludge gasification in a broad temperature range. The results showed that dioxins levels were different to the gasification feedstock's chlorine content and temperature. High chlorine amounts in the feedstock caused dioxin formation, mainly at below $800{ }^{\circ} \mathrm{C}$. Above $800^{\circ} \mathrm{C}$, dioxins levels were significantly reduced, along with corresponding tar levels [42]. The minimum concentration of dioxins set by most current European legislation is $0.1 \mathrm{ngm}^{3}$ expressed in I-TEQ units [43]. It can be concluded that high-temperature gasification depresses dioxin PCDD/F formation when high-chlorine content fuels are used [40]; however, PCDD/F is formed at high temperatures but under an insufficient oxygen environment [44].

Another important effective measure is syngas rapid cooling by water immersion, which impedes the synthesis of PCDD/Fs [45]. During wood gasification, dioxin compounds remain on the surface and then are removed by fly ash particles [46]. This signifies the importance of emission control measurements to successfully alleviate this part of the PCDD/Fs emission in the producer gas. Utilizing high quality wood fuel, optimizing 
combustion conditions, and precipitating the fly ash at temperatures below $200{ }^{\circ} \mathrm{C}$ should be taken into consideration [47].

Multi-step absorption filters are effective in removing dioxins from the gas or cooling effluent [48-54]. Volatile organic compounds, such as dioxins and other organics, are effectively eliminated in the gaseous and liquid phases due to the high-temperature reactor and shock cooling $[16,55]$.

The quality of char, and syngas produced from the gasification of solid wastes degrades in the presence of chlorinated compounds and leads to dioxin formation. In gasification, the majority of the chlorine content is captured as $\mathrm{HCl}$ and $\mathrm{KCl}$ into the syngas, but some organic chlorinated compounds will be formed in oil/tar and char [56]. Gasification is known to decrease corrosion and emission by preserving alkali and heavy metals (apart from mercury and cadmium), sulfur, and chlorine in the process residues, impeding $\mathrm{PCDD} / \mathrm{Fs}$ formation and decreasing the formation of thermal NOx as a consequence of lower temperatures and reducing conditions [57].

\section{Overview of Experimental Measurements of Dioxin Formation Levels in Pyrolysis and Gasification}

A brief description of pyrolysis, gasification experiments, and reports on dioxin formations is provided here and also in Table 1.

Figure 1 shows a summary of the dioxin measurements, based on different substrates that have been gasified and the operational temperature, in the literature reviewed. The pie charts show what feedstock and temperatures have been investigated with experimental measurements and how often in relation to the presence of dioxin. Any publication that reported sampling and analysis of PCDD/Fs and subsequently either detected PCDD/Fs (which includes zero results) or did not detect any measurable level down to $0.1 \mathrm{ng}$ $\mathrm{TEQ} / \mathrm{Nm}^{3}$ is counted.
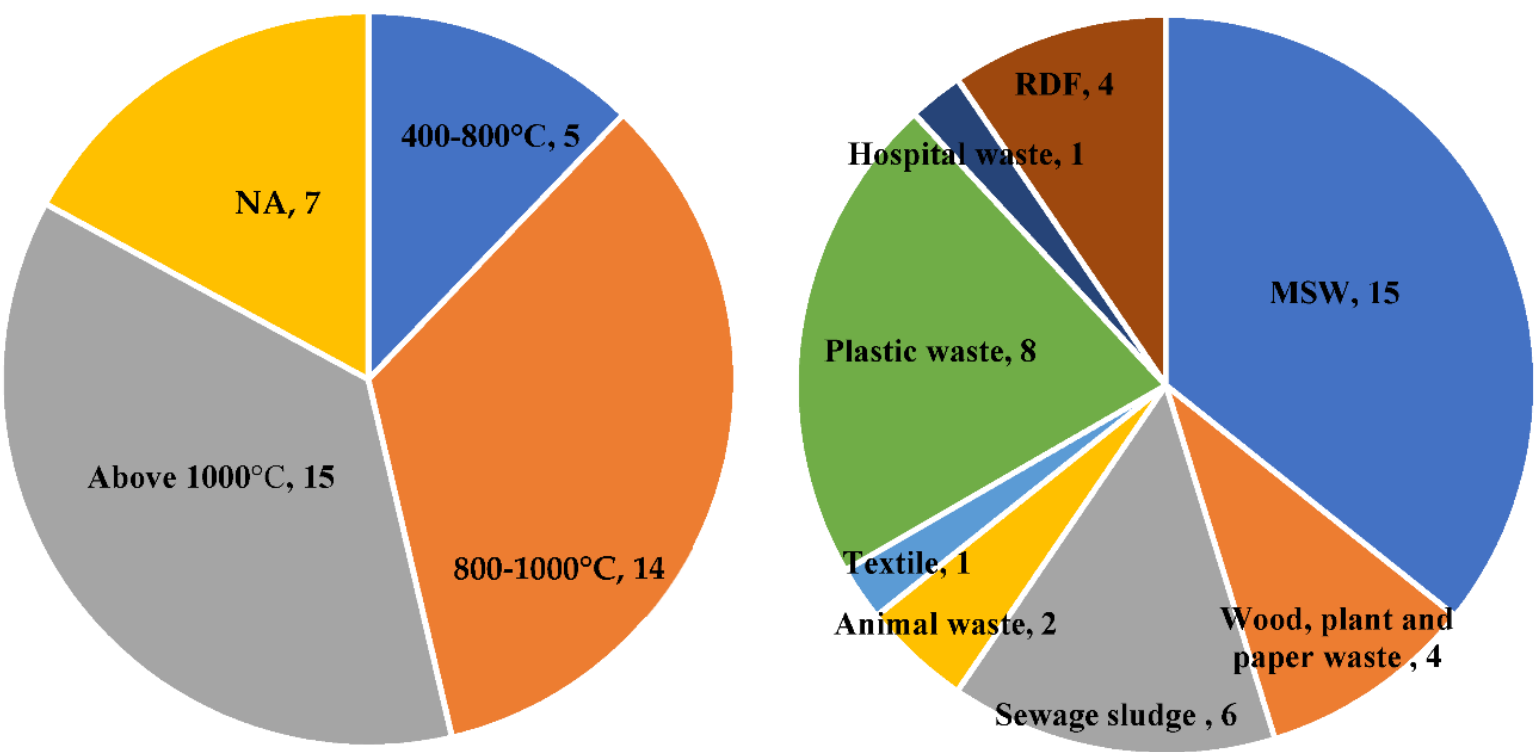

Figure 1. Dioxin measurements, based on different substrates that have been gasified and the operational temperature in the reviewed literature. Dioxin measurements from gasification of different substrates in lab-, pilot-, and full-scale studies (papers from 1990-2021). The pie-charts illustrate the number of times that researchers tried to measure dioxin for each substrate type (chart on the right); and the number of times that dioxin was measured for each substrate. type gasified based on the temperature. The total number of occurrences is greater than the number of articles because several articles discuss more than one substrate type. The selections cover all the reports in the literature measuring dioxin in gasification. 
Figure 2 indicates what conditions (temperatures or feedstock) more frequently result in the presence of dioxin. For example, for MSW, the first measurement (light blue bar) was done at $1400{ }^{\circ} \mathrm{C}$ and the corresponding measured dioxin is 0.0059 . Clustered bar charts are used to show how frequently an attempt was made to detect dioxin, how often it was found, and how much was found. It is noted that RDF (RDF is industrial waste with a high chlorine content) and textiles (waste with a high sulfur content coming from vulcanized material) as feedstock generally result in relatively high dioxin levels, while the gasification of plastics generally results in low dioxin levels independent of the gasification temperature. Wood and paper waste as feedstock also typically result in relatively low dioxin levels except in one report. Dioxin emissions from the gasification of MSW have been the most frequently studied because its formation from MSW incineration has always been the main concern. In particular, reports measuring dioxin formation over a wide range of gasifier operating temperatures $\left(600-1400{ }^{\circ} \mathrm{C}\right)$ exist for MSW. For RDF, however, dioxin formation has only been studied for gasifiers operating around $800^{\circ} \mathrm{C}$. Studies on textiles, hospital waste, animal waste, and wood and paper waste are relatively limited as well. It is expected that dioxin formation decreases at higher temperatures as most of the literature states. This is the case when the substrate is sewage sludge, but there is no difference in the dioxin concentration at different temperatures when the feedstock is MSW or plastics.

Figure 3 illustrates the correlation of the amount of dioxins that was measured with feedstock types and temperatures (process temperature). Since the reported dioxin levels differ, a log plot was created to show the correlation. This figure shows that gasification does not necessarily result in PCDD/Fs formation below the acceptable limits $\left(<0.1 \mathrm{ng} \mathrm{TEQ} / \mathrm{Nm}^{3}\right)$. There are not enough studies measuring PCDD/Fs formation in gasification. It is evidenced, with the data gathered in this review, that there is a strong relation between high temperature and less dioxins formation for almost all feedstock types. It can be seen from the plot that the PCDD/Fs concentrations reported for RDF and textile tend to be more than an order of magnitude higher compared to other feedstock because of their high chlorine and sulfur content. Researchers $[58,59]$ showed that a high-temperature reactor and gas cooling, in the absence of oxygen, prevents PCDD/F formation by de novo synthesis reactions [60]. Thus, this resulted in dioxin-free high-calorie gas production when high chlorine level feedstock was used. Most of the chlorine in the waste was converted to hydrogen chloride in the off gas [61]. When gasifying wastes, especially for MSW and sewage sludge, with temperatures above $1000^{\circ} \mathrm{C}, \mathrm{PCDD} / \mathrm{Fs}$ concentrations are within acceptable limits.

The correlation of the amount of dioxins that was measured with feedstock types and temperatures (process temperature) based on the type of gasification technology used is shown in Figure 4. The effect of using gas cooling methods and high temperatures on dioxin formation of different feedstock even for those with high chlorine contents (such as RDF and plastics) is shown in Figure 5. Gas cooling suppressed dioxins emission to a very low level. Experiments showed the regeneration of PCDD/Fs occurring during slow gas cooling after high-temperature treatment [62]. The general trend in the field is that dioxin concentrations decrease as temperature increases. The trend lines for each case may not fit very tight, but the best fit lines always slope downwards, showing the correlation between the PCDD/Fs concentrations and the temperatures. Figures 4 and 5 show a strong correlation for MSW and sewage sludge with existing data. For other feedstock, it is not possible to look for a trend as there are not enough studies and thus data available in the literature.

For MSW, the most frequently studied feedstock, there is a correlation but also an outlier at temperatures below $1000{ }^{\circ} \mathrm{C}$. Researchers stated that they did not consider any treatment (such as cooling methods) for the product gases, which could be the reason for the dioxin concentration being above the standard limits [16]. 

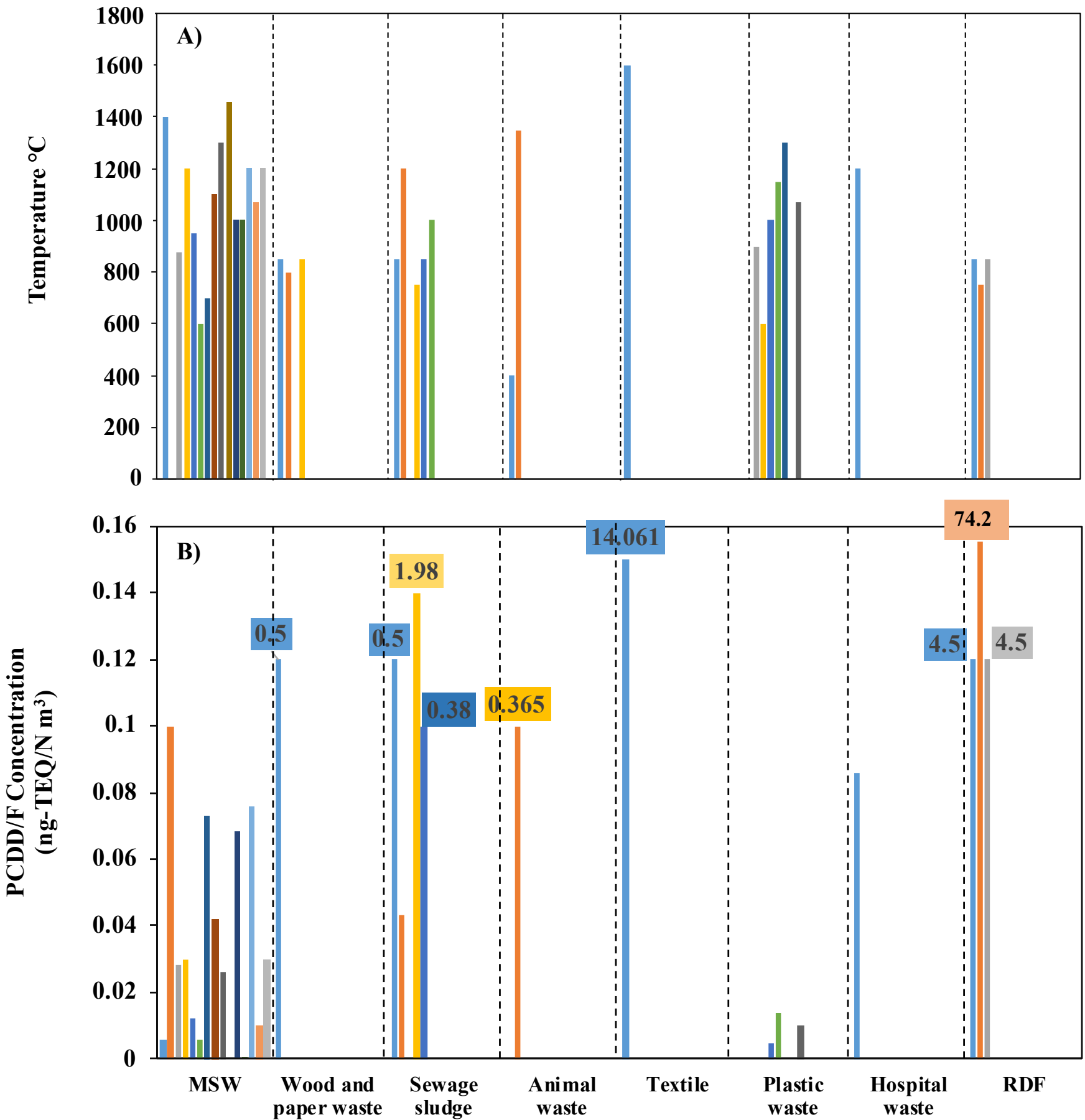

Figure 2. The bar chart on the top shows the temperature at which the dioxin was measured (A). The bar chart at the bottom shows the dioxin concentration based on the feedstock used in the literature (B). There is one cluster of bars for each substrate. Each one of these clusters has a few thin bars right next to each other, meaning that every measurement reported has its own bar, even the ones that measured zero dioxin or below the detection limit (empty space between bars). Since the measured concentration of PCDD/Fs reported for different substrates varies a lot, the $\mathrm{Y}$ axis has to be broken more than once. To make it easier for readers, the real values of measured PCDD/Fs were added on top of some of the bars for which a higher amount of PCDD/Fs has been reported. The dashed black lines are for ease of reading and separating the substrates from each other. 


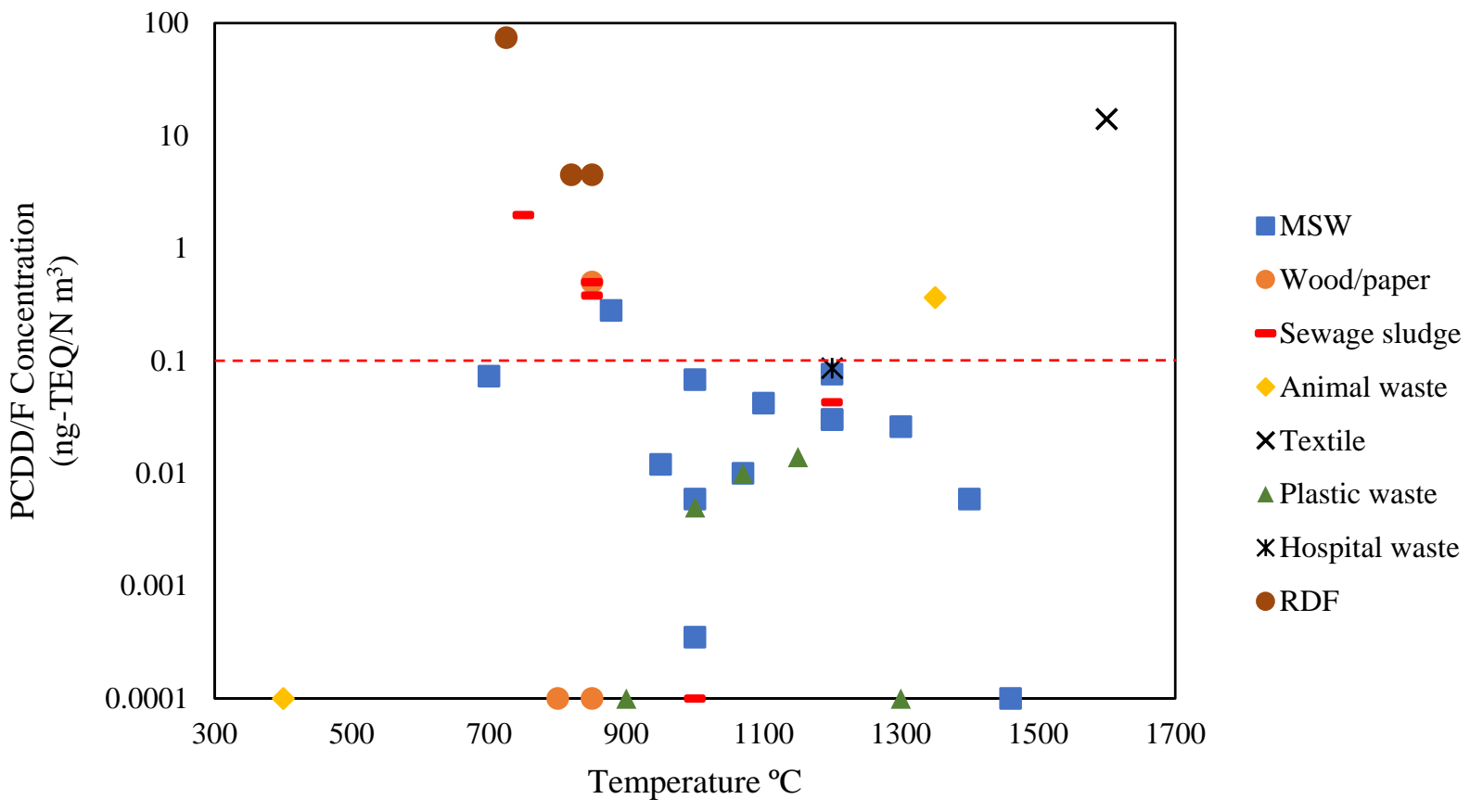

Figure 3. The scatter chart shows the PCDD/Fs concentrations for different feedstock versus temperature. Data points that are Scheme $0\left(\mathrm{ng}-\mathrm{TEQ} / \mathrm{Nm}^{3}\right)$ are those measurements with dioxin concentration below the detection limit or zero dioxin. As it is not possible to put zero values on a logarithmic axis, the red dashed line is the acceptable limit as determined by national and international organizations $\left(<0.1 \mathrm{ng} \mathrm{TEQ} / \mathrm{Nm}^{3}\right)$.

For sewage sludge as well as MSW, there are usually several parameters affecting dioxin formation, but above $1000{ }^{\circ} \mathrm{C}$, it is mainly the temperature that has the most dominant effect. Studies $[63,64]$ showed that that more than $99.9 \%$ of dioxins are decomposed during MSW gasification and that most heavy metals are solidified when the temperature is $1100{ }^{\circ} \mathrm{C}$.

For RDF, which is the high chlorine content feedstock, there are only three data points available. There are no data points for temperatures higher than $850{ }^{\circ} \mathrm{C}$, and thus it is not possible to talk about a trend here.

For plastics, there are several data points for high-temperature measurements but nothing for low-temperature measurements in the existing literature. In the high-temperature region, it seems a trend exists, but whether this trend extends into the low temperature region is currently untested. Researchers studied the effect of chlorine content on dioxins formation by mixing plastic waste with PVC (as PVC is high in chlorine) [61,65]. Results showed that all PCDD/Fs concentrations were within the standard limits, which proves the effect of the high-temperature treatment and the gas cooling $[61,62,66]$.

For wood waste, there is one measurement that is above the limit. This measurement was reported by the Energy research Centre of the Netherlands, who implemented an oilbased gas washing (OLGA) process in a biomass gasifier in order to remove dioxins from the product gas [42]. The dioxin concentration of the product gas was $0.5 \mathrm{ng}$ TEQ/ $\mathrm{Nm}^{3}$ where no OLGA was applied, while it was a factor 10 lower when the gas was purified using the OLGA scrubber. Other measurements presented in the plot are within the acceptable limit, thanks to rapid gas cooling [67].

For animal waste, very little data are available, one of which is hydrothermal gasification of chicken manure at $400{ }^{\circ} \mathrm{C}$, where PCDDs and PCDFs were not detected [68]. The other study shows the result of cogasification of biofermenting residue (BR) at 1300 to $1400{ }^{\circ} \mathrm{C}$. The dioxins emission was calculated to be $0.365 \pm 0.23 \mathrm{ng}$-TEQ $/ \mathrm{Nm}^{3}$, which is far beyond the limits in the EU. This BR contains starch, fish meal, yeast powder, etc., and is 
identified as a hazardous waste according to the national hazardous wastes classification, proposed by the Ministry of Environmental Protection of China [69].

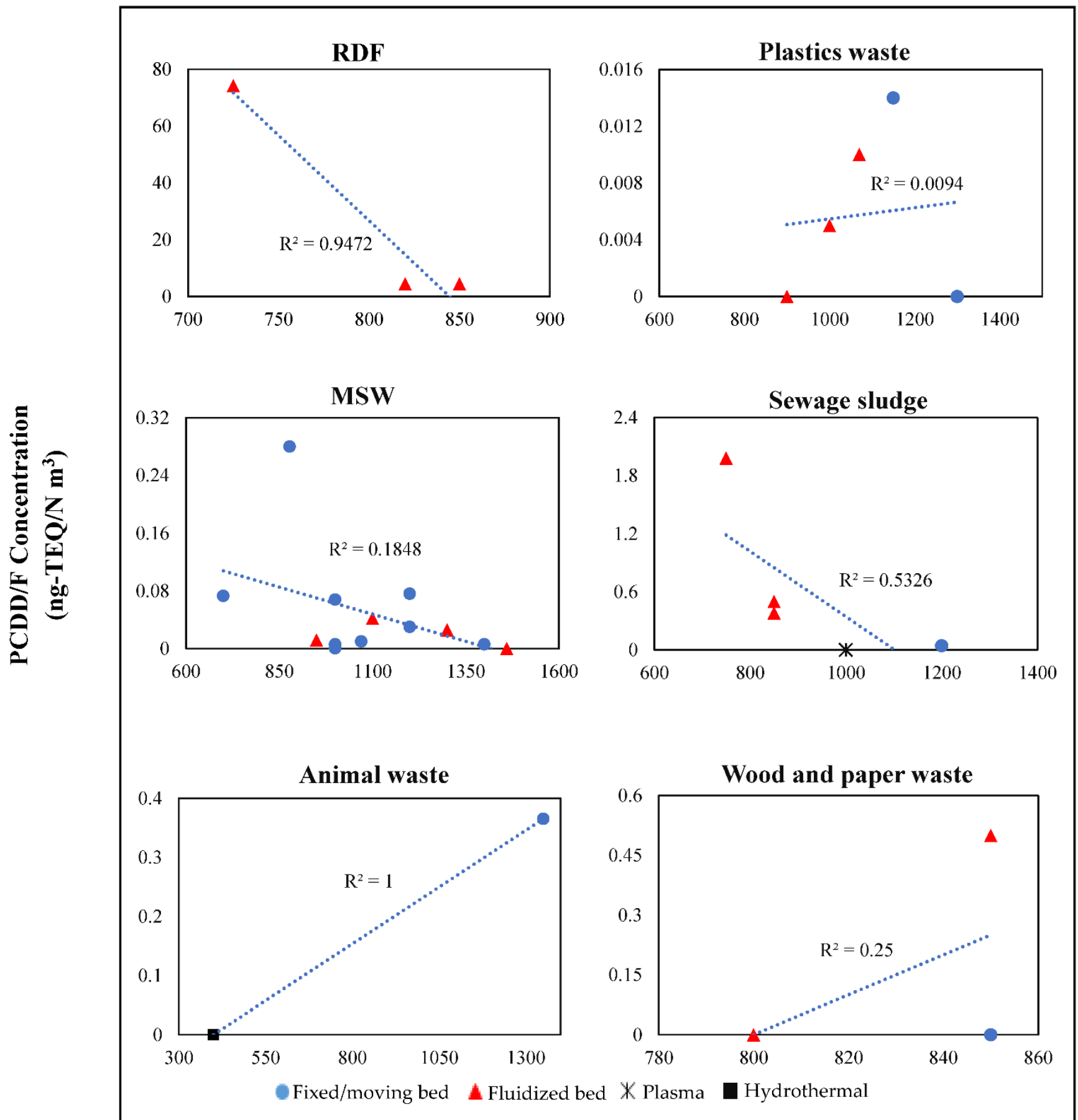

Temperature ${ }^{\circ} \mathrm{C}$

Figure 4. The scatter chart shows the PCDD/Fs concentrations for each feedstock versus temperature. As the number of data points is not enough in the existing literature, it is not possible to say how temperature and PCDD/Fs concentrations correlate for any specific feedstock type, except for MSW, which are the most studied feedstock. Since there is only one study experimenting with textile and hospital waste, they are not included in this figure. 


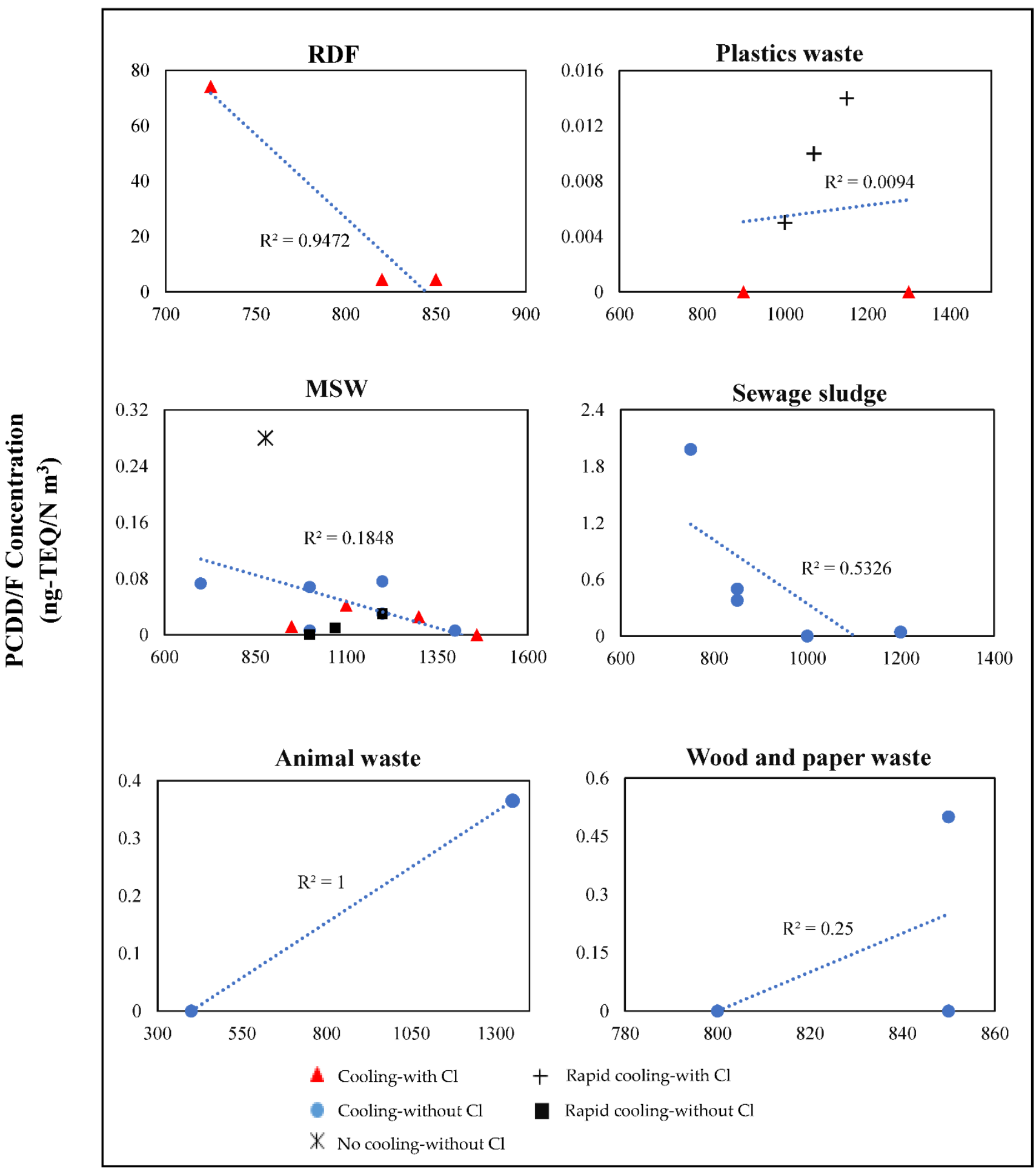

Temperature $^{\circ} \mathrm{C}$

Figure 5. The scatter chart shows the PCDD/Fs concentrations for each feedstock versus temperature. Since there is only one study experimenting with textile and hospital waste, they are not included in this figure. The symbols show if any cooling methods/rapid cooling were used and whether high-chlorine-level feedstock were used.

The formation of PCDD/F compounds in thermochemical processes is indeed the outcome of a complex set of competing chemical reactions. Specific operating settings result 
in PCDD/F formation involving deficient combustion of fuel, the presence of a chlorine source [45,70], oxidizing atmosphere between 10 and $15 \%$ oxygen in the cooling zone [71], fly ash with degenerated graphical structures, fly ash surface acting as a carbon source, temperature range between 250 and $450{ }^{\circ} \mathrm{C}$, and the existence of catalytic metals such as copper, iron, manganese, and zinc [72]. However, in gasification, these conditions are not satisfied, or are less common or fleeting, and hence, the likelihood of detection of PCDD/Fs compounds in the producer gas is low. The specific conditions by which the gasifier runs the gasification process prevents the formation of free chlorine from $\mathrm{HCl}$, thus confining the chlorination of any species in the producer gas [73]. In conclusion, high temperature and gas cooling are by the most effective parameters eliminating dioxins formation in gasification even for feedstock with a chlorine content, while gasifier types play a less important role in dioxin formation prevention as shown in Figures 4 and 5.

Table 1. Emission of dioxins from various combustion, pyrolysis, and gasification sources.

\begin{tabular}{|c|c|c|c|c|c|c|c|}
\hline Technology & Feedstock & Reactor Type & $\begin{array}{c}\text { Temperature } \\
\left({ }^{\circ} \mathrm{C}\right)\end{array}$ & $\begin{array}{c}\text { PCDD/F } \\
\text { Emission } \\
\left.\text { (ng-TEQ/Nm }{ }^{3}\right)\end{array}$ & Syngas Info. & Note & Ref. \\
\hline Gasification & MSW & $\begin{array}{l}\text { Moving grit } \\
\text { gasifier }\end{array}$ & 877.82 & 0.28 & - & $\begin{array}{l}\text { dioxin concentration } \\
\text { below the allowed } \\
\text { value set by the } \\
\text { Brazilian legislation } \\
\text { (0.5), USA ( } 0.1 \text { to } 0.3 \\
\text { for new plants and } \\
0.3 \text { to } 0.8 \text { for existing } \\
\text { plants), Canada ( } 0.5) \text {. }\end{array}$ & [16] \\
\hline Combustion & $\begin{array}{l}\text { Different types } \\
\text { of wood chips } \\
\text { and waste } \\
\text { wood }\end{array}$ & $\begin{array}{l}\text { Moving grate, } \\
\text { Grate burner, } \\
\text { Fluidized bed }\end{array}$ & $\begin{array}{l}\text { Temperature is } \\
\text { not reported, } \\
\text { burners vary in } \\
\text { power from } \\
500 \mathrm{~kW} \text { to } \\
10 \mathrm{MW}\end{array}$ & $0.0027-9.57$ & - & $\begin{array}{l}\text { Emissions from grate } \\
\text { burners when using } \\
\text { wood pellets goes } \\
\text { below allowed value. }\end{array}$ & [3] \\
\hline Gasification & $\begin{array}{l}\text { Torrefied wood } \\
\text { pellet }\end{array}$ & $\begin{array}{l}\text { Downdraft } \\
\text { GEK gasifier }\end{array}$ & 850 & $\begin{array}{l}\text { Lower than the } \\
\text { limit }\end{array}$ & - & - & [70] \\
\hline Gasification & $\begin{array}{l}\text { Sewage sludge } \\
\text { with wood } \\
\text { pellets }\end{array}$ & $\begin{array}{c}\text { Fixed-bed } \\
\text { updraft }\end{array}$ & 1010-1394 & 0.043 & - & $\begin{array}{l}\text { PCDD/Fs were } \\
\text { completely destroyed } \\
\text { at temperatures } \\
\text { above } 600{ }^{\circ} \mathrm{C} .\end{array}$ & [21] \\
\hline Gasification & MSW & Thermoselect & $1200-1600$ & 0.03 & $\begin{array}{c}\mathrm{CO} 25-34 \% \\
\mathrm{H}_{2} 28-38 \% \\
\text { HHV of syngas } \\
\text { varies from } \\
10.88-14.65 \\
\mathrm{MJ} / \mathrm{Nm}^{3}\end{array}$ & - & [55] \\
\hline Gasification & MSW & $\begin{array}{l}\text { Fixed bed } \\
\text { Thermoselect }\end{array}$ & 1200 & 0.03 & $\begin{array}{c}\mathrm{CO} 27-40 \% \\
\mathrm{H}_{2} 36-40 \% \\
\text { Heating value } \\
8-10.2 \\
\mathrm{MJ} / \mathrm{Nm}^{3}\end{array}$ & - & [74] \\
\hline $\begin{array}{l}\text { Pyrolysis and } \\
\text { combustion }\end{array}$ & Animal wastes & $\begin{array}{l}\text { Horizontal } \\
\text { furnace }\end{array}$ & $600-1100$ & $\begin{array}{l}\text { The highest for } \\
\text { pyrolysis at } \\
850^{\circ} \mathrm{C} \text { was } \\
20.2 \text { and for } \\
\text { combustion } \\
\text { was } 43\end{array}$ & - & - & [75] \\
\hline
\end{tabular}


Table 1. Cont.

\begin{tabular}{|c|c|c|c|c|c|c|c|}
\hline Technology & Feedstock & Reactor Type & $\begin{array}{c}\text { Temperature } \\
\left({ }^{\circ} \mathrm{C}\right)\end{array}$ & $\begin{array}{c}\text { PCDD/F } \\
\text { Emission } \\
\left.\text { (ng-TEQ/Nm }{ }^{3}\right)\end{array}$ & Syngas Info. & Note & Ref. \\
\hline $\begin{array}{l}\text { Pyrolysis and } \\
\text { combustion }\end{array}$ & $\begin{array}{c}\text { Cotton textile, } \\
\text { polyester } \\
\text { textile, } \\
\text { Polyvinyl } \\
\text { chloride (PVC), } \\
\text { sewage sludge, } \\
\text { waste lube oils, } \\
\text { meat and bone } \\
\text { meals, and } \\
\text { paper waste. }\end{array}$ & $\begin{array}{c}\text { Batch } \\
\text { laboratory } \\
\text { scale } \\
\text { Horizontal } \\
\text { tubular reactor }\end{array}$ & 850 & $\begin{array}{c}\text { Combustion: } \\
14.8 \\
14 \\
4500 \\
55 \\
80 \\
40 \\
17 \\
\text { Pyrolysis: } \\
- \\
- \\
215 \\
81 \\
- \\
21 \\
-\end{array}$ & - & $\begin{array}{c}\text { Some } \\
\text { data is not present in } \\
\text { pyrolysis for } \\
\text { materials such as } \\
\text { polyester textiles, } \\
\text { waste lube oil, waste } \\
\text { paper. }\end{array}$ & [76] \\
\hline Gasification & Sewage sludge & Fluidized bed & $750-850$ & $\begin{array}{c}\text { At } 750{ }^{\circ} \mathrm{C} \text { was } \\
1.98 \text { and at } \\
850{ }^{\circ} \mathrm{C} \text { was } \\
0.38\end{array}$ & $\begin{array}{c}\mathrm{CO} 16.8 \% \\
\mathrm{H}_{2} 14.9 \% \\
\mathrm{CO}_{2} 13.5 \% \\
\mathrm{CH}_{4} 4.1 \% \\
\mathrm{~N}_{2} 47 \% \\
\end{array}$ & - & [58] \\
\hline Gasification & RDF & Fluidized bed & $725-820$ & $\begin{array}{c}\text { At } 725^{\circ} \mathrm{C} \text { was } \\
74.2 \text { and at } \\
820^{\circ} \mathrm{C} \text { was } 4.5\end{array}$ & $\begin{array}{c}\mathrm{CO} 12.1 \% \\
\mathrm{H}_{2} 7.1 \% \\
\mathrm{CO}_{2} 13.7 \% \\
\mathrm{CH}_{4} 6.4 \% \\
\mathrm{~N}_{2} 53 \% \\
\end{array}$ & - & [58] \\
\hline Co-gasification & $\begin{array}{c}\text { Coal } \\
\text { and MSW }\end{array}$ & Fluidized bed & $600-950$ & $\begin{array}{c}\text { In raw gas was } \\
0.012 . \\
\text { In flue gas was } \\
0.002 . \\
\text { In exhaust gas } \\
\text { was } 0.005\end{array}$ & $\begin{array}{l}\mathrm{CO} 37 \% \\
\mathrm{H}_{2} 34 \% \\
\mathrm{CO}_{2} 25 \% \\
\mathrm{CH}_{4} 5 \%\end{array}$ & $\begin{array}{l}\text { Flue gases from the } \\
\text { same plant, } \\
\text { contained } \\
0.03 \text { ng-TEQ/Nm } \\
\text { PCDD/F because of } \\
\text { the fraction of plastic } \\
\text { waste from sorting. } \\
\text { The PCDD/F stream } \\
\text { derived with the slag } \\
\text { during an hour is } \\
\text { equal to the stream of } \\
\text { these compounds in } \\
\text { the raw gas. }\end{array}$ & [66] \\
\hline Gasification & MSW & $\begin{array}{l}\text { Direct melting } \\
\text { system }\end{array}$ & 1000 & $\begin{array}{c}\text { In flue gas was } \\
0.0059-0.0082 . \\
\text { In fly ash was } \\
0.18-0.037\end{array}$ & $\begin{array}{l}\mathrm{LHV} \text { of syngas } \\
\mathrm{MJ} / \mathrm{m}^{3} \text { was } \\
4.4-5.9\end{array}$ & - & [77] \\
\hline Gasification & $\begin{array}{l}\text { Chicken } \\
\text { manure }\end{array}$ & $\begin{array}{l}\text { Hydrothermal } \\
\text { gasification }\end{array}$ & $200-400$ & $\begin{array}{l}\mathrm{PCDD} / \mathrm{Fs} \\
\text { were not } \\
\text { detected }\end{array}$ & $\begin{array}{c}\text { Without the } \\
\text { additive } 0.1943 \\
\text { mmol } \mathrm{H}_{2} \\
0.2617 \mathrm{mmol}^{\prime} \\
\mathrm{CO}, 0.0244 \\
\mathrm{mmol} \mathrm{CO}_{2} \\
0.0024 \mathrm{mmol} \\
\mathrm{CH}_{4} \\
\text { With the } \\
\text { additive the } \\
\text { yields of gasses } \\
\text { were } \\
\text { decreased. }\end{array}$ & $\begin{array}{l}\text { The alkaline additive } \\
\mathrm{Ca}(\mathrm{OH})_{2} \text { enhances } \\
\text { the reaction rate of } \\
\text { the hydrothermal } \\
\text { gasification at low } \\
\text { reaction temperature. }\end{array}$ & [68] \\
\hline Gasification & WEEE plastics & - & 1200 & $0.014-0.59$ & - & $\begin{array}{c}\text { The allowed limit by } \\
\text { Japan legislation is } \\
(0.1 \text { to } \\
\left.0.5 \mathrm{ng} \text {-TEQ } / \mathrm{Nm}^{3}\right) \text {. }\end{array}$ & [62] \\
\hline
\end{tabular}


Table 1. Cont.

\begin{tabular}{|c|c|c|c|c|c|c|c|}
\hline Technology & Feedstock & Reactor Type & $\begin{array}{c}\text { Temperature } \\
\left({ }^{\circ} \mathrm{C}\right)\end{array}$ & $\begin{array}{c}\text { PCDD/F } \\
\text { Emission } \\
\left(\text { ng-TEQ/Nm }{ }^{3}\right)\end{array}$ & Syngas Info. & Note & Ref \\
\hline Gasification & $\begin{array}{l}\text { Pelletized and } \\
\text { loose straw }\end{array}$ & Fluidized bed & $792-826$ & $\begin{array}{c}\text { Small } \\
\text { negligible }\end{array}$ & $\begin{array}{c}\text { For pelletized } \\
\text { straw } \\
\mathrm{CO} 13-14 \% \\
\mathrm{H}_{2} 17-18 \% \\
\mathrm{CO}_{2} 16-18 \% \\
\mathrm{CH}_{4} 3-4 \% \\
\mathrm{~N}_{2} 49-50 \% \\
\text { For loose straw } \\
\mathrm{CO} 14-17 \% \\
\mathrm{H}_{2} 8-9 \% \\
\mathrm{CO}_{2} 16-17 \% \\
\mathrm{CH}_{4} 5 \% \\
\mathrm{~N}_{2} 51-54 \% \\
\end{array}$ & $\begin{array}{l}\text { Higher amount of } \\
\text { tars in experiments } \\
\text { with loose straw. } \\
\text { PAHs were present in } \\
\text { large amounts in the } \\
\text { fly ash especially for } \\
\text { loose straw. }\end{array}$ & [67] \\
\hline Gasification & $\begin{array}{l}\text { Biofermenting } \\
\text { residue with } \\
\text { coal-water } \\
\text { slurry }\end{array}$ & $\begin{array}{l}\text { Multicomponent } \\
\text { slurry pressure } \\
\quad \text { gasifier }\end{array}$ & $1300-1400$ & 0.365 & $\begin{array}{l}\mathrm{CO} 43.7 \% \\
\mathrm{H}_{2} 34.2 \% \\
\mathrm{CO}_{2} 18.2 \% \\
\mathrm{CH}_{4} 0.3 \%\end{array}$ & $\begin{array}{c}\text { It meets the PCDD } / F \\
\text { concentration limit of } \\
\text { China } \\
\left(0.5 \mathrm{ng}-\mathrm{TEQ} / \mathrm{Nm}^{3}\right) \\
\text { but is far beyond the } \\
\text { limits in the EU. }\end{array}$ & [69] \\
\hline Gasification & $\begin{array}{l}\text { Carpet and } \\
\text { textile waste }\end{array}$ & $\begin{array}{c}\text { Plasma } \\
\text { gasification }\end{array}$ & 1600 & 14.061 & $\begin{array}{c}\mathrm{CO} 11.7 \% \\
\mathrm{H}_{2} 8.1 \% \\
\mathrm{CO}_{2} 3.1 \% \\
\mathrm{CH}_{4} 1.1 \% \\
\mathrm{O}_{2} 1.1 \%\end{array}$ & $\begin{array}{l}\text { Presence of } \mathrm{Cl} \\
\text { elevates dioxin } \\
\text { formation and the } \\
\text { gas cools down in } \\
200 \text { to } 400^{\circ} \mathrm{C} \text { where } \\
\text { secondary dioxin } \\
\text { formation occurs. }\end{array}$ & [78] \\
\hline Gasification & $\begin{array}{c}\text { MSW } \\
\text { Plastic waste } \\
\text { PVC refuse }\end{array}$ & - & 1000 & $0.0035-0.014$ & - & $\begin{array}{c}\text { The measured values } \\
\text { were converted } \\
\text { assuming } 12 \% \\
\text { oxygen. }\end{array}$ & [65] \\
\hline Gasification & MSW & $\begin{array}{l}\text { Drying, } \\
\text { pyrolysis, } \\
\text { gasification, } \\
\text { combustion, } \\
\text { and ash } \\
\text { vitrification } \\
\text { in one step }\end{array}$ & $600-1200$ & 0.076 & - & - & [79] \\
\hline Gasification & Alfalfa stem & - & - & $\begin{array}{c}\text { Total } \\
\text { chlorinated } \\
\text { dioxin } \\
\text { compounds } \\
\text { were } \\
0.1-0.6 \mu \mathrm{g} / \mathrm{kg}\end{array}$ & - & $\begin{array}{l}\text { The concentrations } \\
\text { both in fly and } \\
\text { bottom ash were as } \\
\text { following: TCDD } \\
\text { was } 0.1 \mu \mathrm{gg} / \mathrm{kg} \text {, } \\
2,3,7,8 \\
\text { trichlorodioxyfuran } \\
\text { was } 0.08 \mu \mathrm{g} / \mathrm{kg}\end{array}$ & [80] \\
\hline Gasification & RDF and PVC & - & $600-1000$ & $\begin{array}{l}\text { Lower than the } \\
\text { limits }\end{array}$ & $\begin{array}{c}\mathrm{CO} 11.4 \% \\
\mathrm{H}_{2} 69.6 \% \\
\mathrm{CO}_{2} 13.5 \% \\
\mathrm{CH}_{4} 5.5 \% \\
\text { Heating value } \\
\text { of } 10.92 \\
\left(\mathrm{MJ} / \mathrm{m}^{3}\right)\end{array}$ & - & [59] \\
\hline
\end{tabular}


Table 1. Cont.

\begin{tabular}{|c|c|c|c|c|c|c|c|}
\hline Technology & Feedstock & Reactor Type & $\begin{array}{c}\text { Temperature } \\
\left({ }^{\circ} \mathrm{C}\right)\end{array}$ & $\begin{array}{c}\text { PCDD/F } \\
\text { Emission } \\
\left.\text { (ng-TEQ/Nm }{ }^{3}\right)\end{array}$ & Syngas Info. & Note & Ref \\
\hline Gasification & MSW & $\begin{array}{c}\text { High } \\
\text { temperature } \\
\text { gasification } \\
\text { and smelting } \\
\text { system }\end{array}$ & 1070 & $\begin{array}{l}\text { Less than } 0.01 \\
\text { ng-TEQ } / \mathrm{Nm}^{3}\end{array}$ & - & $\begin{array}{c}\text { Gasification and } \\
\text { smelting system with } \\
\mathrm{O}_{2} \text { blowing and } \\
\text { drying waste, and } \\
\text { rapid gas cooling } \\
\text { system in } \\
\text { high-temperature } \\
\text { reduction } \\
\text { atmosphere are } \\
\text { effective for dioxin } \\
\text { removal. }\end{array}$ & [81] \\
\hline Gasification & $\begin{array}{l}\text { Plastic waste } \\
\text { and PVC }\end{array}$ & $\begin{array}{l}\text { Sumitomo } \\
\text { Metals } \\
\text { gasification } \\
\text { and smelting } \\
\text { system }\end{array}$ & 1070 & $\begin{array}{l}\text { Less than } 0.01 \\
\text { ng-TEQ/ } \mathrm{Nm}^{3}\end{array}$ & - & - & [61] \\
\hline Gasification & Plastic waste & $\begin{array}{l}\text { Chemical } \\
\text { looping } \\
\text { gasification }\end{array}$ & 900 & $\begin{array}{c}\text { too small to } \\
\text { detect } \\
\text { by using } \\
\text { GC-MS }\end{array}$ & $\begin{array}{l}\mathrm{CO} 21.9 \% \\
\mathrm{H}_{2} 12.7 \% \\
\mathrm{CO}_{2} 7.8 \% \\
\mathrm{CH}_{4} 5.9 \% \\
\mathrm{~N}_{2} 50.7 \%\end{array}$ & - & [82] \\
\hline Gasification & Hospital waste & $\begin{array}{l}\text { Drying, } \\
\text { pyrolysis, } \\
\text { gasification, } \\
\text { combustion, } \\
\text { and ash } \\
\text { vitrification } \\
\text { in one step }\end{array}$ & $600-1200$ & 0.0861 & - & - & [83] \\
\hline Gasification & MSW & $\begin{array}{l}\text { Industrial- } \\
\text { sized power } \\
\text { plant }\end{array}$ & 1400 & $\begin{array}{l}\text { In clean fuel } \\
\text { gas was } \\
0.00003 \text { to } \\
0.0059 \text { and in } \\
\text { exhaust gas } \\
\text { was } 0.0000082 \\
\text { to } 0.0031\end{array}$ & $\begin{array}{c}\mathrm{CO} 15.6 \% \\
\mathrm{H}_{2} 11.9 \% \\
\mathrm{CO}_{2} 15.3 \% \\
\mathrm{CH}_{4} 1.1 \% \\
\mathrm{~N}_{2} 55.1 \% \\
\text { Heating } \\
\text { value of } \\
3700\left(\mathrm{~kJ} / \mathrm{m}^{3} \mathrm{~N}\right)\end{array}$ & - & [84] \\
\hline
\end{tabular}

\section{Conclusions}

Dioxin formation/emission via combusting waste is of great public concern. Gasification offers a sustainable substitute approach for waste treatment and energy generation. Gasification is an environmentally friendly technology that enables operation within current regulatory restrictions.

In the presence of organic carbon, oxygen, and chlorine, all combustion processes can result in the formation of $\mathrm{PCDD} / \mathrm{F}$ in the temperature range $200-800^{\circ} \mathrm{C}$. However, dioxins formation is significantly reduced if a high-temperature reactor is used at above $800{ }^{\circ} \mathrm{C}$ and shock cooling of gases is combined, without the presence of oxygen. Dioxin formation can be reduced with the aid of high-temperature gasification even in the problematic case of having fuels with a high content of chlorine.

$\mathrm{PCDD} / \mathrm{Fs}$ formation in gasification has not been well investigated in the literature. In this review, the levels of PCDD/Fs measured in emissions during gasification of wastes were discussed. There are only few studies available in the literature considering and measuring dioxin formation in waste gasification, and all were reviewed in this paper.

More research should be carried out regarding dioxin formation in gasification. Topics could include:

- Gasification of wastes other than those mentioned in this review; 
- The inhibitors of dioxin formation in gasification, such as sulfur- or nitrogen-containing agents.

Author Contributions: A.S.: Conceptualization, formal analysis, investigation, methodology, writing-original draft. C.R.: supervision, writing-review \& editing. R.U.: funding acquisition, supervision, writing - review \& editing. All authors have read and agreed to the published version of the manuscript.

Funding: Waste2 Gas: project no. 175326-0611, funded by the Rannis Technology Development Fund and SW-GROW, project no. 366, funded by the Northern Periphery and Arctic Programme.

Acknowledgments: Financial support was provided by the Rannís Technology Development Fund (project 175326-0611), and the Northern Periphery and Arctic program (project 366).

Conflicts of Interest: The authors declare no conflict of interest.

\section{References}

1. Cheung, W.H.; Lee, V.K.C.; McKay, G. Minimizing dioxin emissions from integrated MSW thermal treatment. Environ. Sci. Technol. 2007, 41, 2001-2007. [CrossRef] [PubMed]

2. Cunliffe, A.M.; Williams, P.T. De-novo formation of dioxins and furans and the memory effect in waste incineration flue gases. Waste Manag. 2009, 29, 739-748. [CrossRef]

3. Lavric, E.D.; Konnov, A.A.; De Ruyck, J. Dioxin levels in wood combustion-A review. Biomass Bioenergy 2004, 26, 115-145. [CrossRef]

4. Environment Australia. Incineration and Dioxins Review of Formation Processes. A Consultancy Funded by Environment Australia Department of the Environment and Heritage; Environment Australia: Canberra, Australia, 1999; Volume 42.

5. Huang, H.; Buekens, A. On the mechanisms of dioxin formation in combustion processes. Chemosphere 1995, 31, 4099-4117. [CrossRef]

6. Altarawneh, M.; Dlugogorski, B.Z.; Kennedy, E.M.; Mackie, J.C. Mechanisms for formation, chlorination, dechlorination and destruction of polychlorinated dibenzo- p -dioxins and dibenzofurans (PCDD/Fs). Prog. Energy Combust. Sci. 2009, 35, $245-274$. [CrossRef]

7. Paladino, O.; Massabò, M. Health risk assessment as an approach to manage an old landfill and to propose integrated solid waste treatment: A case study in Italy. Waste Manag. 2017, 68, 344-354. [CrossRef]

8. Sodhi, K.K.; Kumar, M.; Singh, I.K.; Singh, D.K. Ecological Risk of Dioxin Exposure Dioxin; CRC Press: Boca Raton, FL, USA, 2020; ISBN 9781315170961.

9. National Research Council. Waste Incineration and Public Health; National Academy of Sciences: Washington, DC, USA, 2000; ISBN 0309504465.

10. Martens, D.; Balta-Brouma, K.; Brotsack, R.; Michalke, B.; Schramel, P.; Klimm, C.; Henkeimann, B.; Oxynos, K. Chemical impact of uncontrolled solid waste combustion to the vicinity of the Kouroupitos Ravine, Crete, Greece. Chemosphere 1998, 36, $2855-2866$. [CrossRef]

11. Huang, H.; Buekens, A. De novo synthesis of polychlorinated dibenzo-p -dioxins and dibenzofurans Proposal of a mechanistic scheme. Sci. Total Environ. 1996, 193, 121-141. [CrossRef]

12. Tosti, S.; Sousa, M.A.; Buceti, G.; Madeira, L.M.; Pozio, A. Process analysis of refuse derived fuel hydrogasification for producing SNG. Int. J. Hydrog. Energy 2019, 44, 21470-21480. [CrossRef]

13. Kirkels, A.F.; Verbong, G.P.J. Biomass gasification: Still promising? A 30-year global overview. Renew. Sustain. Energy Rev. 2011, 15, 471-481. [CrossRef]

14. Basu, P. Biomass Gasification, Pyrolysis and Torrefaction Practical Design and Theory, 2nd ed.; Elsevier: Amsterdam, The Netherlands, 2013.

15. Knoef, H.; Ahrenfeldt, J. Handbook Biomass Gasification; BTG Biomass Technology Group: Enschede, The Netherlands, 2005.

16. Lopes, E.J.; Okamura, L.A.; Yamamoto, C.I. Formation of dioxins and furans during municipal solid waste gasification. Braz. J. Chem. Eng. 2015, 32, 87-97. [CrossRef]

17. Panepinto, D.; Tedesco, V.; Brizio, E.; Genon, G. Environmental Performances and Energy Efficiency for MSW Gasification Treatment. Waste Biomass Valorization 2014, 6, 123-135. [CrossRef]

18. Thakare, S.; Nandi, S. Study on Potential of Gasification Technology for Municipal Solid Waste (MSW) in Pune City. Energy Procedia 2015, 90, 509-517. [CrossRef]

19. Klein, A. Gasification: An Alternative Process for Energy Recovery and Disposal of Municipal Solid Wastes. New York. 2002. Available online: http://www.zetatalk10.com/docs/Gasifiers/Gasification_Of_Municipal_Solid_Wastes_2002.pdf (accessed on 30 May 2002).

20. Xu, P.; Jin, Y.; Cheng, Y. Thermodynamic Analysis of the Gasification of Municipal Solid Waste. Engineering 2017, 3, 416-422. [CrossRef] 
21. Seggiani, M.; Puccini, M.; Raggio, G.; Vitolo, S. Effect of sewage sludge content on gas quality and solid residues produced by cogasification in an updraft gasifier. Waste Manag. 2012, 32, 1826-1834. [CrossRef]

22. Werther, J.; Ogada, T. Sewage sludge combustion. Prog. Energy Combust. Sci. 1999, 25, 55-116. [CrossRef]

23. Costner, B.P.; Cray, W.C.; Martin, G.; Rice, B.; Santillo, D.; Stringer, R. PVC: A Primary Contributor to the U.S. Dioxin Burden; Citeseer: Princeton, NJ, USA, 1995.

24. Safavi, S.M.; Richter, C.; Unnthorsson, R. Dioxin and Furan Emissions from Gasification. In Gasification; IntechOpen: London, $\mathrm{UK}, 2021$.

25. Zhang, M.; Buekens, A.; Li, X. Brominated flame retardants and the formation of dioxins and furans in fires and combustion. $J$. Hazard. Mater. 2016, 304, 26-39. [CrossRef]

26. Duwel, U.; Nottrodt, A.; Ballschmiter, K. Simultaneous sampling of PCDD/PCDF inside the combustion chamber and on four boiler levels of a waste incineration plant. Chemosphere 1990, 20, 1839-1846. [CrossRef]

27. Maric, J.; Berdugo Vilches, T.; Pissot, S.; Cañete Vela, I.; Gyllenhammar, M.; Seemann, M. Emissions of dioxins and furans during steam gasification of Automotive Shredder residue; experiences from the Chalmers 2-4-MW indirect gasifier. Waste Manag. 2020, 102, 114-121. [CrossRef] [PubMed]

28. McKay, G. Dioxin characterisation, formation and minimisation during municipal solid waste (MSW) incineration: Review. Chem. Eng. J. 2002, 86, 343-368. [CrossRef]

29. Tame, N.W.; Dlugogorski, B.Z.; Kennedy, E.M. Formation of dioxins and furans during combustion of treated wood. Prog. Energy Combust. Sci. 2007, 33, 384-408. [CrossRef]

30. Sippula, O.; Lind, T.; Jokiniemi, J. Effects of chlorine and sulphur on particle formation in wood combustion performed in a laboratory scale reactor. Fuel 2008, 87, 2425-2436. [CrossRef]

31. Lu, S.; Yan, J.; Li, X.; Ni, M.; Cen, K.; Dai, H. Effects of inorganic chlorine source on dioxin formation using fly ash from a fluidized bed incinerator. J. Environ. Sci. 2007, 19, 756-761. [CrossRef]

32. Baumgärtel, G. The Siemens Thermal Waste Recycling Process-A modern technology for converting waste into usable products. J. Anal. Appl. Pyrolysis 1993, 27, 15-23. [CrossRef]

33. Schubert, R.; Stahlberg, R. Advanced Continuous In-line Gasification and Vitrification of Solid Waste. Sustain. Dev. Int. 1999, 1, 37-40.

34. Zhang, M.; Yang, J.; Buekens, A.; Olie, K.; Li, X. PCDD/F catalysis by metal chlorides and oxides. Chemosphere 2016, 159, 536-544. [CrossRef]

35. Zhang, R.-Z.; Wang, L.-Z.; Yin, R.-H.; Luo, Y.-H. Alteration in formation behaviors of chloroaromatic precursors of PCDD/Fs: An experimental study on the effect of extrinsic and intrinsic oxygen on chlorination. Chemosphere 2020, 243, 125319. [CrossRef]

36. Liu, W.; Zheng, M.; Zhang, B.; Qian, Y.; Ma, X.; Liu, W. Inhibition of PCDD/Fs formation from dioxin precursors by calcium oxide. Chemosphere 2005, 60, 785-790. [CrossRef]

37. Ma, J.; Wang, J.; Tian, X.; Zhao, H. In-situ gasification chemical looping combustion of plastic waste in a semi-continuously operated fluidized bed reactor. Proc. Combust. Inst. 2019, 37, 4389-4397. [CrossRef]

38. Zhao, X.; Zhou, H.; Sikarwar, V.S.; Zhao, M.; Park, A.H.A.; Fennell, P.S.; Shen, L.; Fan, L.S. Biomass-based chemical looping technologies: The good, the bad and the future. Energy Environ. Sci. 2017, 10, 1885-1910. [CrossRef]

39. Cai, J.; Zheng, W.; Luo, M.; Kuang, C.; Tang, X. Characterization of copper (II) chemical forms and heavy metal distribution in chemical looping gasification of municipal solid waste. J. Energy Inst. 2021, 96, 140-147. [CrossRef]

40. Kamińska-Pietrzak, N.; Smoliński, A. Selected Environmental Aspects of Gasification and Co-Gasification of Various Types of Waste. J. Sustain. Min. 2013, 12, 6-13. [CrossRef]

41. Cai, J.; Zeng, R.; Zheng, W.; Wang, S.; Han, J.; Li, K.; Luo, M.; Tang, X. Synergistic effects of co-gasification of municipal solid waste and biomass in fixed-bed gasifier. Process Saf. Environ. Prot. 2021, 148, 1-12. [CrossRef]

42. Zwart, R.W.R.; Van der Drift, A.; Bos, A.; Visser, H.J.M.; Cieplik, M.K.; Könemann, H.W.J. Oil-based gas washing-Flexible tar removal for high-efficient production of clean heat and power as well as sustainable fuels and chemicals. Environ. Prog. Sustain. Energy 2009, 28, 324-335. [CrossRef]

43. Ferraz, M.C.M.A.; Afonso, S.A.V. Dioxin Emission Factors for the Incineration of Different Medical Waste Types. Environ. Contam. Toxicol. 2003, 44, 460-466. [CrossRef] [PubMed]

44. Walker literature review of formation and release of PCDD/Fs from gas manufacturing. Chemosphere 1997, 35, 1409-1422 [CrossRef]

45. Maya, D.M.Y.; Sarmiento, A.L.E.; Oliveira, C.A.V.B.d.; Lora, E.E.S.; Andrade, R.V. Gasification of Municipal Solid Waste for Power Generation in Brazil, a Review of Available Technologies and Their Environmental Benefits. J. Chem. Chem. Eng. 2016, 10, $249-255$. [CrossRef]

46. Chagger, H.K.; Kendall, A.; McDonald, A.; Pourkashanian, M.; Williams, A. Formation of dioxins and other semi-volatile organic compounds in biomass combustion. Appl. Energy 1998, 60, 101-114. [CrossRef]

47. Lind, T.; Kauppinen, E.I.; Hokkinen, J.; Jokiniemi, J.K.; Orjala, M.; Aurela, M.; Hillamo, R. Effect of Chlorine and Sulfur on Fine Particle Formation in Pilot-Scale CFBC of Biomass. Energy Fuels 2006, 20, 61-68. [CrossRef]

48. Dannecker, W.; Hemschemeier, H. Level of activated-coke technology for flue gas dust collection behind refuse destruction plants looking at the problem from the special aspects of dioxin separation. Organohalogen Compd. 1990, 4, 267. 
49. Pařízek, T.; Bébar, L.; Stehlík, P. Persistent pollutants emission abatement in waste-to-energy systems. Clean Technol. Environ. Policy 2008, 10, 147-153. [CrossRef]

50. Hiraoka, M.; Takizawa, Y.; Masuda, Y.; Takeshita, R.; Yagome, K.; Tanaka, M.; Watanabe, Y.; Morikawa, K. Investigation on generation of dioxins and related compounds from municipal incinerators in Japan. Chemosphere 1987, 16, 1901-1906. [CrossRef]

51. Goemans, M.; Clarysse, P.; Joannès, J.; De Clercq, P.; Lenaerts, S.; Matthys, K.; Boels, K. Catalytic NOx reduction with simultaneous dioxin and furan oxidation. Chemosphere 2003, 50, 489-497. [CrossRef]

52. Kojima, N.; Mitomo, A.; Itaya, Y.; Mori, S.; Yoshida, S. Adsorption removal of pollutants by active cokes produced from sludge in the energy recycle process of wastes. Waste Manag. 2002, 22, 399-404. [CrossRef]

53. Bonte, J.L.; Fritsky, K.J.; Plinke, M.A.; Wilken, M. Catalytic destruction of PCDD/F in a fabric filter: Experience at a municipal waste incinerator in Belgium. Waste Manag. 2002, 22, 421-426. [CrossRef]

54. Inoue, K.; Yasuda, K.; Kawamoto, K. Report: Atmospheric pollutants discharged from municipal solid waste incineration and gasification-melting facilities in Japan. Waste Manag. Res. 2009, 27, 617-622. [CrossRef]

55. Kwak, T.-H.; Lee, S.; Park, J.-W.; Maken, S.; Yoo, Y.D.; Lee, S.-H. Gasification of municipal solid waste in a pilot plant and its impact on environment. Korean J. Chem. Eng. 2006, 23, 954-960. [CrossRef]

56. Lu, P.; Huang, Q.; Bourtsalas, A.T.; Themelis, N.J.; Chi, Y.; Yan, J. Review on fate of chlorine during thermal processing of solid wastes. J. Environ. Sci. 2019, 78, 13-28. [CrossRef]

57. Mukherjee, A.; Debnath, B.; Ghosh, S.K. A Review on Technologies of Removal of Dioxins and Furans from Incinerator Flue Gas. Procedia Environ. Sci. 2016, 35, 528-540. [CrossRef]

58. Van Paasen, S.; Cieplik, M.; Phokawat, N. Gasification of Non-Woody Biomass; Technical Report; ECN: Petten, The Netherlands, 2006.

59. Borgianni, C.; De Filippis, P.; Pochetti, F.; Paolucci, M. Gasification process of wastes containing PVC. Fuel 2002, 81, 1827-1833. [CrossRef]

60. Huang, H.; Buekens, A. Chemical kinetic modeling of de novo synthesis of PCDD/F in municipal waste incinerators. Chemosphere 2001, 44, 1505-1510. [CrossRef]

61. Yamamoto, T.; Sato, H.; Matsukura, Y.; Ujisawa, Y.; Ishida, H.; Sasaki, S.; Hata, Y. Gasification and smelting system using oxygen blowing for plastic waste including polyvinyl chloride. J. Mater. Cycles Waste Manag. 2004, 6, 6-12. [CrossRef]

62. Yamawaki, T. The gasification recycling technology of plastics WEEE containing brominated flame retardants. Fire Mater. 2003, 27, 315-319. [CrossRef]

63. Xiao, G.; Jin, B.-S.; Zhong, Z.-P.; Chi, Y.; NI, M.-J.; Cen, K.-F.; Xiao, R.; Huang, Y.-J.; Huang, H. Experimental study on MSW gasification and melting technology. J. Environ. Sci. 2007, 19, 1398-1403. [CrossRef]

64. Hu, B.; Huang, Q.; Chi, Y.; Yan, J. Polychlorinated dibenzo-p-dioxins and dibenzofurans in a three-stage municipal solid waste gasifier. J. Clean. Prod. 2019, 86, 1279-1296. [CrossRef]

65. Kikuchi, R.; Sato, H.; Matsukura, Y.; Yamamoto, T. Semi-pilot scale test for production of hydrogen-rich fuel gas from different wastes by means of a gasification and smelting process with oxygen multi-blowing. Fuel Process. Technol. 2005, 86, 1279-1296. [CrossRef]

66. Adlhoch, W.; Sato, H.; Wolff, J.; Radtke, K. High-temperature Winkler gasification of municipal solid waste. Gasif. Technol. Conf. 2000, 8, 1-15.

67. Asikainen, A.H.; Kuusisto, M.P.; Hiltunen, M.A.; Ruuskanen, J. Occurrence and Destruction of PAHs, PCBs, ClPhs, ClBzs, and PCDD/Fs in Ash from Gasification of Straw. Environ. Sci. Technol. 2002, 36, 2193-2197. [CrossRef] [PubMed]

68. Bircan, S.Y.; Matsumoto, K.; Kitagaw, K. Environmental Impacts of Hydrogen Production by Hydrothermal Gasification of a Real Biowaste. In Gasification for Practical Applications; InTech Open: London, UK, 2012; p. 15. ISBN 9789537619992.

69. Du, Y.; Jiang, X.; Ma, X.; Tang, L.; Wang, M.; Lv, G.; Jin, Y.; Wang, F.; Chi, Y.; Yan, J. Cogasification of biofermenting residue in a coal-water slurry gasifier. Energy Fuels 2014, 28, 2054-2058. [CrossRef]

70. Rollinson, A.N.; Williams, O. Experiments on torrefied wood pellet: Study by gasification and characterization for waste biomass to energy applications. R. Soc. Open Sci. 2016, 3, 150578. [CrossRef] [PubMed]

71. Wu, S.; Azharuddin, M.; Sasaoka, E. Characteristics of the removal of mercury vapor in coal derived fuel gas over iron oxide sorbents. Fuel 2006, 85, 213-218. [CrossRef]

72. Behrend, P.; Krishnamoorthy, B. Considerations for waste gasification as an alternative to landfilling in Washington state using decision analysis and optimization. Sustain. Prod. Consum. 2017, 12, 170-179. [CrossRef]

73. Prabhansu; Karmakar, M.K.; Chandra, P.; Chatterjee, P.K. A review on the fuel gas cleaning technologies in gasification process. $J$. Environ. Chem. Eng. 2015, 3, 689-702. [CrossRef]

74. Kwak, T.H.; Maken, S.; Lee, S.; Park, J.W.; Min, B.-R.; Yoo, Y.D. Environmental aspects of gasification of Korean municipal solid waste in a pilot plant. Fuel 2006, 85, 2012-2017. [CrossRef]

75. Conesa, J.A.; Fullana, A.; Font, R. Dioxin production during the thermal treatment of meat and bone meal residues. Chemosphere 2005, 59, 85-90. [CrossRef] [PubMed]

76. Conesa, J.A.; Font, R.; Fullana, A.; Martín-Gullón, I.; Aracil, I.; Gálvez, A.; Moltó, J.; Gómez-Rico, M.F. Comparison between emissions from the pyrolysis and combustion of different wastes. J. Anal. Appl. Pyrolysis 2009, 84, 95-102. [CrossRef]

77. Tanigaki, N.; Manako, K.; Osada, M. Co-gasification of municipal solid waste and material recovery in a large-scale gasification and melting system. Waste Manag. 2012, 32, 667-675. [CrossRef] [PubMed] 
78. Lemmens, B.; Elslander, H.; Vanderreydt, I.; Peys, K.; Diels, L.; Oosterlinck, M.; Joos, M. Assessment of plasma gasification of high caloric waste streams. Waste Manag. 2007, 27, 1562-1569. [CrossRef] [PubMed]

79. Liu, Y.; Liu, Y. Novel incineration technology integrated with drying, pyrolysis, gasification, and combustion of MSW and ashes vitrification. Environ. Sci. Technol. 2005, 39, 3855-3863. [CrossRef]

80. Mozaffari, M.; Rosen, C.J.; Russelle, M.P.; Nater, E.A. Chemical Characterization of Ash from Gasification of Alfalfa Stems: Implications for Ash Management. J. Environ. Qual. 2000, 29, 963. [CrossRef]

81. Yamamoto, T.; Isaka, K.; Sato, H.; Matsukura, Y.; Ishida, H. Gasification and Smelting System Using Oxygen Blowing for Municipal Waste. ISIJ Int. 2008, 40, 260-265. [CrossRef]

82. Wang, J.; Zhao, H. Application of CaO-Decorated Iron Ore for Inhibiting Chlorobenzene during in Situ Gasification Chemical Looping Combustion of Plastic Waste. Energy Fuels 2016, 30, 5999-6008. [CrossRef]

83. Liu, Y.; Ma, L.; Liu, Y.; Kong, G. Investigation of Novel Incineration Technology for Hospital Waste. Environ. Sci. Technol. 2006, 40, 6411-6417. [CrossRef] [PubMed]

84. Noma, T.; Ide, K.; Yoshikawa, J.; Kojo, K.; Matsui, H.; Nakajima, R.; Imai, K. Development of waste gasification and gas reforming system for municipal solid waste (MSW). J. Mater. Cycles Waste Manag. 2012, 14, 153-161. [CrossRef] 